\title{
Experience with veno-venous ecmo in patients with adult respiratory distress syndrome secondary to viral pneumonia. Case series
}

\author{
Experiencia con ecmo veno-venoso en pacientes con síndrome de dificultad \\ respira toria del adulto secundario a neumonía viral. Serie de casos \\ Antonio Figueredo ${ }^{a}$, Leonardo Salazar ${ }^{b}$, Camilo E. Pizarroc, Mauricio Orozco-Levi ${ }^{\mathrm{d}}$ (iD, \\ Maria M. Botia ${ }^{\text {iD }}$ \\ ${ }^{a}$ Cardiovascular Surgery Department, Fundación Cardiovascular de Colombia, Floridablanca, Colombia \\ b ECMO (Extracorporeal Membrane Oxygenation) and Artificial Heart Department, Fundación Cardiovascular de Colombia, Floridablanca, Colombia \\ ' Intensive Care Department, Fundación Cardiovascular de Colombia, Floridablanca, Colombia \\ d Pulmonology Department, Hospital Internacional de Colombia, Piedecuesta, Colombia.
}

Correspondence: Departamento de Cirugía Cardiovascular, Fundación Cardiovascular de Colombia. Calle 155 ㄱ. 23-58. Bucaramanga, Colombia Email:mariabotia@fcv.org

What do we know about this issue?

Among patients who suffer it, adult respiratory distress syndrome continues to be associated with high mortality rates, and it can occur secondary to viral pneumonia. Fundacion Cardiovascular is a reference center for the management of patients with this disease requiring veno-venous ECMO. This is a retrospective study with a small number of cases, but with acceptable results.

\section{¿What is this study's contribution?}

In view of the current viral pandemic and of potential future epidemics, we decided to share our experience, mortality and complications, as they can be useful for other clinical centers that are beginning to use this therapy.

\section{How to cite this article?}

Figueredo A, Salazar L, Pizarro CE, OrozcoLevi $M$, Botia MM. Experience with venovenous ecmo in patients with adult respiratory distress syndrome secondary to viral pneumonia. Case series. Colombian Journal of Anesthesiology. 2020;48(4):e933.

\section{Abstract}

\section{Introduction}

The use of extracorporeal membrane oxygenation (ECMO) has increased exponentially in recent years and has shown to be effective in treating adult respiratory distress syndrome (ARDS) secondary to $\mathrm{H}_{1} \mathrm{~N}_{1}$-related pneumonia. However, evidence remains controversial. This study describes a case series of ECMO in ARDS secondary to viral pneumonia.

\section{Methods}

A search was conducted in the ECMO database of Fundación Cardiovascular de Colombia for the 20132017 period. A case series report was written of patients diagnosed with ARDS secondary to confirmed or suspected viral pneumonia.

\section{Results}

Nineteen patients with ECMO support and ARDS due to viral pneumonia were included in the study. The survival rate upon discharge was 11 patients (58\%) and weaning from ECMO support was successful in 13 patients $(68 \%)$. Hemorrhagic complications were the most frequent: gastrointestinal bleeding, 10 patients (53\%); intracranial bleeding, 2 (10\%); alveolar hemorrhage, 2 (10\%); hemothorax requiring thoracostomy with chest tube drainage, 2 (10\%); cannulation site bleeding, 9 patients (47\%); and surgical site bleeding in 3 patients $(25 \%)$ who required tracheostomy. Other complications were: pneumothorax, 1 patient (5\%); sepsis, 6 patients (32\%); and growth of microorganisms in bronchial lavage, 6 patients (32\%).

\section{Conclusions}

This study supports the use of veno-venous ECMO to achieve a higher survival rate than expected in patients with severe ARDS and refractory hypoxemia secondary to viral pneumonia. Early initiation of the therapy should improve overall results.

\section{Keywords}

Extracorporeal membrane oxygenation; $\mathrm{H}_{1} \mathrm{~N} 1$; adult respiratory distress syndrome; viral pneumonia; veno-venous. 
¿Qué sabemos acerca de este problema?

El síndrome de dificultad respiratoria del adulto (SDRA) continua teniendo una alta mortalidad entre las personas que lo padecen, y este puede producirse secundario a una neumonía viral. La Fundación Cardiovascular es un centro de referencia para el manejo de pacientes con esta enfermedad que requieren oxigenación por membrana extracorpórea (ECMO por sus siglas en inglés) con sistema veno-venoso. El presente estudio, si bien tiene un número pequeño de casos, muestra resultados aceptables.

\section{¿Qué aportade nuevo este estudio?}

En vista de la actual pandemia viral y la posibilidad de epidemias futuras, decidimos compartir nuestra experiencia $y$ nuestros datos de mortalidad y complicaciones porque creemos que pueden ser útiles para otros centros que comienzan a utilizar esta terapia.

\section{Resumen}

\section{Introducción}

El uso de la oxigenación por membrana extracorpórea (ECMO) ha tenido un incremento exponencial en los últimos años y ha demostrado ser efectivo en el manejo del síndrome de dificultad respiratoria del adulto (SDRA) secundario a neumonía por $\mathrm{H}_{1} \mathrm{~N}_{1}$, si bien la evidencia sigue siendo controvertida. En este estudio describimos una serie de casos de ECMO por SDRA secundario a neumonía viral.

\section{Métodos}

Se realizó una búsqueda en la base de datos de ECMO de la Fundación Cardiovascular desde el año 20132017. Reportamos una serie de casos donde se incluyeron pacientes diagnosticados con SDRA secundario a neumonía viral sospechosa o confirmada.

\section{Resultados}

Se incluyeron en el estudio 19 pacientes con soporte de ECMO y SDRA por neumonía viral. La sobrevida al alta fue 11 pacientes (58\%) y el destete del ECMO fue exitoso en 13 pacientes (68\%). Las complicaciones hemorrágicas presentadas fueron: sangrado digestivo, 10 pacientes (53\%), sangrado cerebral, 2 (10\%), hemorragia alveolar, 2 (10\%), hemotórax con requerimiento de toracostomía a drenaje cerrado, $2(10 \%)$, sangrado activo por sitio de canulación, 9 pacientes (53\%), y 3 pacientes traqueostomizados (25\%) que sangraron por el sitio quirúrgico. Otras complicaciones presentadas fueron: neumotórax, 1 paciente (5\%), septicemia, 6 (32\%) y crecimiento de microorganismos en lavados bronquiales $6(32 \%)$.

\section{Conclusion}

El presente estudio permite indicar que el uso de la ECMO VV viabiliza una sobrevida mayor a la esperada en pacientes con SDRA severo e hipoxemia refractaria secundario a neumonía viral. Su inicio tempranamente debe mejorar los resultados globales.

\section{Palabras clave}

Oxigenación por membrana extracorpórea; $\mathrm{H}_{1} \mathrm{~N}_{1}$; síndrome de dificultad respiratoria del adulto; neumonía viral; veno-venoso.

were hospitalized. Their mortality rate varies from 5 to $10 \%$ (1).

In January 2018, the Colombian Ministry

Health systems around the world have had to confront different viral epidemics and pandemics repeatedly. Among them, those that developed as a result of the influenza A $\mathrm{H}_{1} \mathrm{~N}_{1}$ virus or their related diseases, are to be highlighted. They have become the focus of considerable research due to the significant morbidity and mortality at any age, especially during the COVID-19 pandemic.

The Center for Disease Control and Prevention calculated a high rate of flurelated hospitalizations for the 2016-2017 period. In the United States, approximately 30.9 million people fell ill, 14.5 million sought medical consultation and 600,000 of Health reported 289 cases of influenza between November 19, 2017, and January 13 , 2018, with $9(3.1 \%)$ deaths. Of these cases, 258 were Influenza $A\left(\mathrm{H}_{1} \mathrm{~N}_{1}\right), 24$ were $A\left(\mathrm{H}_{3} \mathrm{~N}_{2}\right)$ and 7 were influenza $B$.

The influenza $A\left(\mathrm{H}_{1} \mathrm{~N}_{1}\right)$ infection can lead to pneumonia and severe ARDS with refractory hypoxemia. Cases with failed conventional treatment can be managed with ECMO support, with the aim of providing adequate gas exchange(1).

Veno-venous ECMO (VV-ECMO) provides support for the lungs only. One or two cannulas are placed in large veins on the side of the neck or in the groin area at the top of the leg. The heart will continue to work normally. The ECMO machine will drain the blood from the vein through the cannula, oxygen will be added to the blood, carbon dioxide will be removed, and then the blood is warmed and returned back to the right side of the heart through the cannula. The heart pumps the oxygenated blood to the body, allowing the lungs to rest and recover.

Data collected in the ELSO (Extracorporeal Life Support Organization) Statistical Reports up to January 2017 reported the presence of 350 centers with 12,346 adult patients cannulated for ECMO respiratory support and a survival rate of $66 \%$. Moreover, they identified an exponential increase 
in the use of ECMO support attributed to epidemics caused by influenza $A\left(\mathrm{H}_{1} \mathrm{~N}_{1}\right)$ infection.

The first randomized clinical trial carried out in England and published in 2009 was the CESAR study, which included 180 patients with severe ARDS assigned to two groups: VV ECMO support, or conventional treatment. The survival rate was $63 \%$ for patients with ECMO support compared to $47 \%$ for patients with conventional treatment(2). These results were promising as regards the use of ECMO for this condition. A second international randomized trial of ECMO in severe acute respiratory distress syndrome (EOLIA) was published in 2018. Patients with a $\mathrm{PaFiO} 2 / \mathrm{FiO}_{2}$ less than $50 \mathrm{mmHC}$ for more than 3 Hours, a $\mathrm{PaFiO} 2 / \mathrm{FiO}_{2}$ less than $80 \mathrm{mmHG}$ for more than 6 Hours or an arterial $\mathrm{pH}$ of less than 7.25 and $\mathrm{PCO}_{2}$ more than $60 \mathrm{mmHG}$ despite the use of optimized protective lung ventilation were randomized to receive ECMO vs medical therapy. At 60 days, mortality was $35 \%$ in the ECMO group and $46 \%$ in the control group, a difference that did not reach common statistical significance. However, a Bayesian analysis of this study later found a high probability of survival improvement in these patients with the use of ECMO.

Our aim was to describe our experience with the treatment of severe ARDS secondary to viral pneumonia using VVECMO in a reference center for national and international patients in Colombia.

\section{METHODS}

Case series study using medical records. Collected and reported data included epidemiological and demographic details, viral agent isolates, duration of ECMO support in days, complications experienced, survival rate, and ECMO circuit information.

Asearch in the Fundación Cardiovascular de Colombia ECMO database resulted in 83 patients over 16 years of age who received VV-ECMO during the five-year period between 2013 and 2017; after filtering by diagnosis of viral pneumonia, 19 patients met this inclusion criterion.
All patients had severe ARDS, according to the Berlin ARDS definition(3), and were cannulated for VV ECMO if they had a persistent partial pressure of oxygen/ fraction of inspired oxygen $(\mathrm{PaFi})<100$ with a fraction of inspired oxygen $>90 \%$ despite optimal medical treatment for 6 hours or less. Patients from other institutions were transferred using air or ground transportation. Figure 1 shows a chest X-Ray in a patient with ARDS.

Multiplex polymerase chain reaction (PCR) serological tests were used to confirm the diagnosis of the viral agent. For patients outside the virus detection window, the clinical presentation and the epidemiological exposure were used as the diagnostic criteria.

A Bio-Console 560 and Affinity CP cone by Medtronic ${ }^{\circledR}$ were used for VV ECMO support with a LivaNova $^{\circledR}$ EOS ECMO oxygenator and circuit. Initially, two venous access were used (right internal jugular and femoral veins) in all patients; some cases were converted to a single Avalon bi-caval dual lumen cannula (Abbott $\left.{ }^{\circledR}\right)$.

At the time of admission, all patients underwent a CT scan of the head, chest and abdomen. During ECMO support, circuit change was performed upon obtaining results of plasma free hemoglobin greater than $50 \mathrm{mg} / \mathrm{dl}$ and/or clinical signs of hemolysis, and in the event of cone and/or oxygenator malfunction.

Flexible bronchoscopy and echocardiography were performed in all patients, along with endoscopic procedures of the gastrointestinal tract as needed under guidance of the clinician.

Systemic anticoagulation was indicated up until ECMO withdrawal, and the goal was to maintain PTT (partial thromboplastin time) at 1.5 to 2 times its normal value. In the event of massive bleeding or

FIGURA 1. Chest X-Ray in a patient with adult respiratory distress syndrome (ARDS).

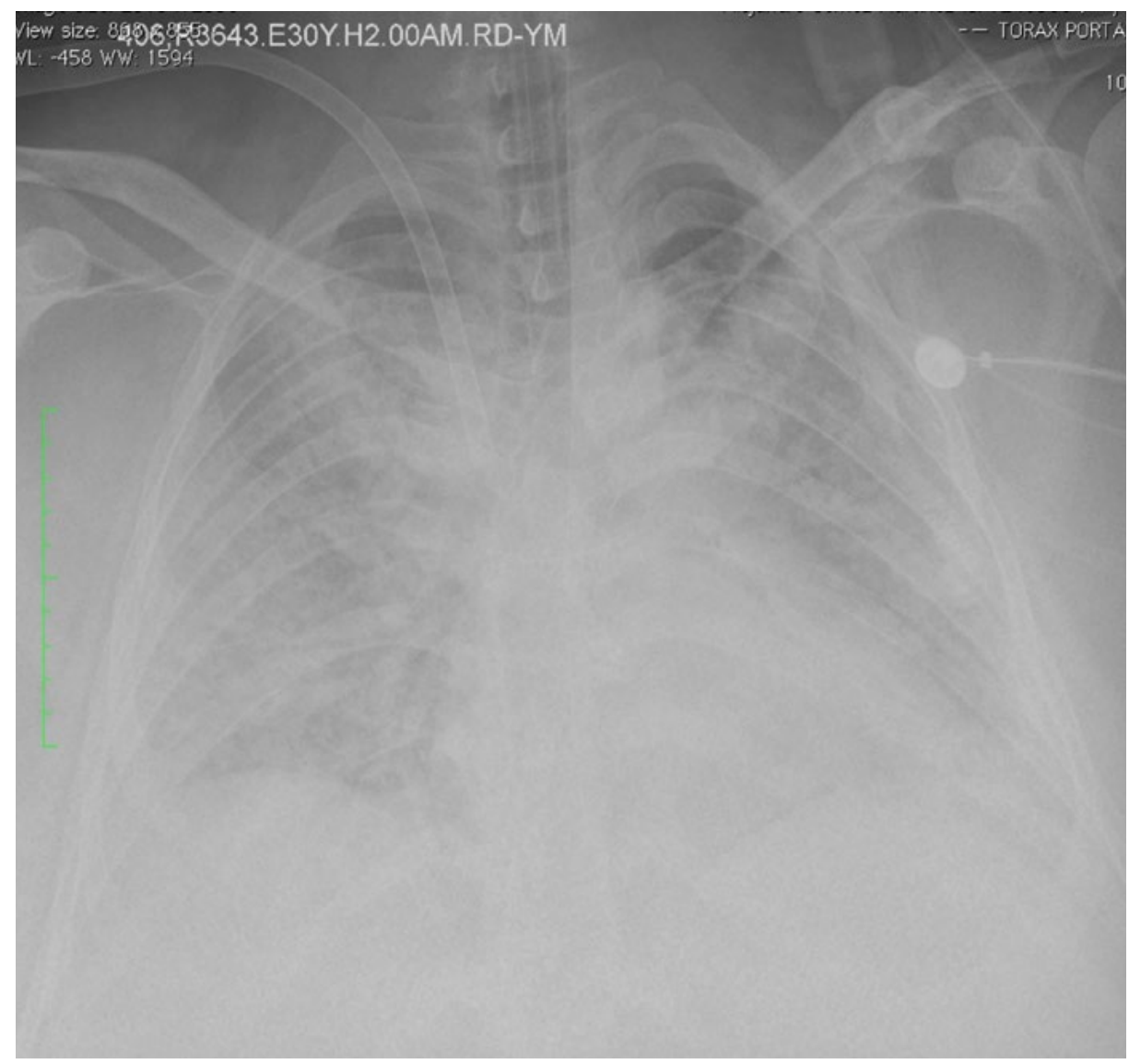

SOURCE: Authors. 
intracranial bleeding, anticoagulation was discontinued and restarted according to the patient's clinical course.

Once ECMO was introduced, mechanical ventilation was managed with parameters at rest, in pressure-controlled mode with PEEP 5-10 cm H2O, a peak inspiratory pressure of $20-25 \mathrm{~mm} \mathrm{Hg}$, a respiratory rate of 10-12 per minute, a fraction of inspired oxygen between 30 to $40 \%$ and, when allowed based on the clinical condition, patients were managed with spontaneous ventilation.

\section{RESULTS}

A total of 19 patients met the inclusion criteria. The median age was 51 years (range of $17-67), 9$ patients were men (47\%), 8 (49\%) had a past medical history of hypertension, and 5 (26\%) had type 2 diabetes mellitus. None of the patients had chronic renal injury.

Six international patients (32\%) were flown in from Aruba, Curaçao and Ecuador. Five $(26 \%)$ of the $12(63 \%)$ national patients needed ground transportation, 4 (21\%)

TABLE 1. Patient demographics.

\begin{tabular}{|c|c|}
\hline $\begin{array}{c}\text { Patient } \\
\text { characteristics }\end{array}$ & $(n=19)$ \\
\hline Age (years) & $51(17-67)$ \\
Sex & \\
-Male & $9(47 \%)$ \\
-Female & $10(53 \%)$ \\
\hline Hypertension & $8(49 \%)$ \\
\hline Type 2 Diabetes & \\
Mellitus & $5(26 \%)$ \\
\hline Renal failure & $0(0 \%)$ \\
\hline Smoking & $3(16 \%)$ \\
\hline SOFA (points) & $12(7-26)$ \\
\hline International patients & $6(32 \%)$ \\
\hline National patients & $13(68 \%)$ \\
Source: Authors. & \\
\hline Sequential organ failure assessment.
\end{tabular}

were transported by air and 3 (16\%) were cannulated at our institution. The multiplex PCR test was performed in 16 patients (84\%), of whom 8 (42\%) tested positive for influenza $A\left(\mathrm{H}_{1} \mathrm{~N} 1\right), 1$ (5\%) tested positive for $\mathrm{H}_{2} \mathrm{~N}_{3}$, while the remaining cases were suspicious due to clinical symptoms and epidemiological nexus. Patient characteristics are shown in Table 1.

The severity of the disease was demonstrated by the high 12-point median value on the Sequential organ failure assessment (SOFA) score (range of 7-26), with an estimated mortality greater than $80 \%$. The median mechanical ventilation time prior to ECMO was 4 days (range of 1 - 34) and the prone position strategy was used with 16 patients (84\%). Prior to cannulation, 2 patients $(10 \%)$ required tracheostomy, 12 (63\%) required tracheostomy during ECMO, and 1 patient (5\%) required tracheostomy after weaning from ECMO. The median of ECMO support time was 20 days (range of 6-236).

Renal injury requiring replacement therapy with hemodialysis occurred in 9 patients (47\%), and 4 patients $(21 \%)$ were started on hemodialysis prior to ECMO. Kidney failure was reverted in all patients before discharge.

TABLE 2. Complications and procedures during extracorporeal membrane oxygenation (ECMO) support.

\section{Complications and procedures}

Frequency and proportion of patients $(n=19)$
The hemorrhagic complications were: gastrointestinal bleeding, 10 patients (53\%); alveolar hemorrhage, 2 (10\%); hemothorax requiring thoracostomy with chest tube drainage, 2 (10\%); intracranial bleeding, 2 (10\%); active bleeding from cannulation site, 9 (47\%); and surgical site bleeding in 3 patients (25\%) who required tracheostomy. Other complications were: pneumothorax 1 patient (5\%), sepsis 6 (32\%), and growth of microorganisms in bronchial lavage 6 (32\%). Complications and procedures are shown in Table 2.

Blood product transfusions were required in $100 \%$ of patients, with a median of 18 units of red blood cells (range of 3 145), 3 units of platelets (range of $0-44$ ), 5 units of cryoprecipitate (range of o-52) and 2 units of fresh frozen plasma (range of o34).

ECMO circuit changes were required twice per patient (range of 1 - 9), ECMO weaning was successful in 13 patients (68\%), and the survival rate at discharge was 11 patients (58\%). Among the patients who died while on ECMO support, four suffered brain death secondary to resuscitation ( 1 patient), intracranial bleeding (2 patients), and ischemic stroke ( 1 patient). The other

\begin{tabular}{|l|c|}
\hline \multicolumn{1}{|c}{ Complications and procedures } & $\begin{array}{c}\text { Frequency and proportion } \\
\text { of patients }(n=19)\end{array}$ \\
\hline $\begin{array}{l}\text { Hemorrhagic complication } \\
\text { - Gastrointestinal bleeding }\end{array}$ & $10(53 \%)$ \\
-Alveolar hemorrhage & $2(10 \%)$ \\
- Hemothorax requiring chest tube & $2(10 \%)$ \\
-Cannulation site bleeding & $9(47 \%)$ \\
-Surgical site bleeding (tracheostomy) & $3(25 \%)$ \\
-Intracranial bleeding & $2(10 \%)$ \\
\hline Pneumothorax & $1(6 \%)$ \\
\hline Sepsis & $6(32 \%)$ \\
\hline Microorganisms in bronchial lavage & $6(32 \%)$ \\
\hline Renal injury with hemodialysis & $9(47 \%)$ \\
\hline Tracheostomy & $12(63 \%)$
\end{tabular}

SOURCE: Authors. 
two patients died of septic shock. The cause of post-ECMO weaning death was septic shock.

One of the cases of hemorrhage and brain death was a patient in her 23rd week of pregnancy with a live fetus. The decision was to keep the patient on somatic support due to the extreme prematurity of the fetus, in order to allow for fetal weight gain and lung maturation. During the 26th week of pregnancy, the patient developed hemothorax and anhydramnios, due to which an emergent cesarean section had to be performed, with a live product weighing 750 grams and measuring 31 centimeters. The newborn was discharged after three months, with oxygen by nasal cannula.

\section{DISCUSSION}

The results of ECMO use in our patients with ARDS secondary to viral pneumonia reported a survival rate lower than the one found in two major randomized clinical trials carried out in similar patients. In the CESAR study published in 2009, the survival rate was $63 \%$, and in the most recent EOLIA trial published in May 2018, the rate was $65 \%$ at 60 days (4). However, no direct comparison can be made between survival rates, given that these studies were performed in different time-frames and did not include as many transfer patients as were included in our report.

Days of mechanical ventilation prior to ECMO is among the variables that could have influenced our death rate. Systematic reviews report a median of 2 days $\underline{(5,1)}$ and, in our series, this time was 100\% longer. The cause of this longer time may be attributed to the fact that the majority of our patients were referred from other centers. Patroniti et al. published the experience of a group of Italian centers treating ARDS secondary to the $\mathrm{H}_{1} \mathrm{~N}_{1}$ pandemic of 2009 , finding a survival rate of $71 \%$ in the 49 cases that required ECMO. In that study, the duration of mechanical ventilation prior to cannulation was analyzed, finding that each day of delay increased the probability of the risk of death by $34.8 \%$; also, according to the days of mechanical ventilation prior to cannulation, it estimated that the patients cannulated at 2, 3 or 7 days had a survival rate of 90,76 and $30 \%$, respectively, which leads us to infer the existence of an association between mortality and the number of days of prior respiratory support(6).

For our patients, time on ECMO was longer than found in the literature. A meta-analysis including 8 studies and 266 patients infected by influenza $A\left(\mathrm{H}_{1} \mathrm{~N}_{1}\right)$ who required ECMO reported 8 and 16 days of support time(1). This result is very similar to that found in other case series, such as the reports from two centers in Croatia and Japan, with 8 and 9 days respectively $(7,8)$. Patients with delayed cannulation were very likely to be in a more advanced stage of the disease and in a more critical condition, which may have influenced prolonged ECMO support.

Our maximum time on ECMO support in this series was 236 days in one patient who, despite a long hospital stay, was discharged on home oxygen and independence for daily activities.

Previous influenza $A\left(\mathrm{H}_{1} \mathrm{~N}_{1}\right)$ pandemics have shown that there is an increase in the risk of morbidity and mortality among pregnant women and during the postpartum period. It is believed that the high mortality rates in this population are due to the physiological changes that accompany pregnancy, making women more susceptible to secondary complications (8). In our group, there were one pregnant patient and another woman in the second day of the postpartum period, (10\%) both of whom died while on ECMO support, which also influenced our mortality rate.

Bleeding complications were the most frequent and are comparable to those reported in the literature $(2,6,7)$. The EOLIA trial reported bleeding complications in $53 \%$ of the patients, which is consistent with our results. However, our number of gastrointestinal bleedings is much higher than reported. This difference might be explained by the fact that, due to a lack of availability of ECMO devices, we had to use less hemo-compatible pumps developed for cardiopulmonary bypass.
Few studies report data on the ECMO circuit and the number of changes required per patient. In Japan, in a series of 14 cases requiring ECMO support due to ARDS secondary to $A H_{1} N_{1}$ influenza, Takeda et al. reported a median of 8 days on ECMO support and 2 circuit changes per patient. Although we also performed two changes per patient, our requirements were lower because days on ECMO support were more than double the number of days in Takeda's study.

Mortality in severe ARDS with conventional treatment is high, which motivates us to continue to develop strategies to reduce it, and ECMO is one of the options. However, evidence remains controversial at present. Limitations of our study are the sampling strategy, having a limited number of patients and the fact that it was observational and retrospective.

\section{CONCLUSION}

This observational study suggests that the use of VV-ECMO might improve survival rates in patients with severe ARDS and refractory hypoxemia secondary to viral pneumonia. Early initiation of therapy should improve overall results. The use of less hemo-compatible pumps may be detrimental to patient safety in terms of bleeding complications. Air or ground transport of patients on ECMO support is safe and allows the referral of patients who are in distant centers to sites with greater experience, who could otherwise not be moved without this support, given their critical condition.

\section{ETHICAL DISCLOSURES}

\section{Protection of human and animal subjects}

The authors declare that no experiments were performed on humans or animals for this study. 


\section{Data confidentiality}

The authors declare that they have followed the protocols of their work center regarding the disclosure of patient data.

\section{Right to privacy and informed consent}

The authors declare that no patient data appear in this article. The authors obtained informed consents from the patients and/ or subjects referred to in the article. These documents are kept by the corresponding author.

\section{Ethics committee approval}

This study was approved by the Research Ethics Committee of the Fundación Cardiovascular de Colombia, in a meeting held on August 25, 2020, as recorded in act number 511 .

\section{ACKNOWLEDGEMENTS}

\section{Authors' contributions:}

A. F: Cannulation of patients on ECMO support. REview of the article for publication.

L. S: Follow-up and patient management during their hospital stay. Review and drafting of the article for publication.
C. P: Patient management in the intensive care unit.

M. L-O: Patient follow-up and performance of fiberoptic bronchoscopy as needed.

M. B: Search in the clinical records and patient databases for article preparation and drafting.

\section{Financial support and sponsorship}

Ninguno

\section{Conflicts of interest}

The authors declare that they don't have conflict of interest

\section{REFERENCES}

1. Zangrillo A, Biondi-Zoccai G, Landoni G, Frati G, Patroniti N, Pesenti A, et al. Extracorporeal membrane oxygenation (ECMO) in patients with $\mathrm{H}_{1} \mathrm{~N}_{1}$ influenza infection: A systematic review and meta-analysis including 8 studies and 266 patients receiving ECMO. Crit Care. 2013;17(1):R3O.DOI: ttps://doi.org/10.1186/cc12512

2. Peek G], Mugford M, Tiruvoipati R, Wilson A, Allen E, Thalanany MM, et al. Efficacy and economic assessment of conventional ventilatory support versus extracorporeal membrane oxygenation for severe adult respiratory failure (CESAR): a multicentre randomised controIled trial. Lancet. 2009;374(9698):1351-63. DOI: https://doi.org/10.1016/S0140-6736(09)61069-2
3. Ferguson ND, Fan E, Camporota L, AntoneIli M, Anzueto A, Beale R, et al. The Berlin definition of ARDS: An expanded rationale, justification, and supplementary material. Intensive Care Med. 2012;38(10):1573-82. DOI: https://doi.org/10.1007/s00134-012-2682-1

4. Combes A, Hajage D, Capellier G, Demoule A, Lavoué S, Guervilly C, et al. Extracorporeal Membrane Oxygenation for Severe Acute Respiratory Distress Syndrome. N Engl ] Med. 2018;378(21):1965-75. DOI: 10.1056/NEJMoa1800385

5. Davies A, Jones D, Bailey M, Beca ], Bellomo R, Blackwell N, , et al. Extracorporeal Membrane Oxygenation for 2009 Influenza $A\left(\mathrm{H}_{1} \mathrm{~N} 1\right)$ Acute Respiratory Distress Syndrome. JAMA. 2009;302(17):1888-95. DOI:10.1001/ jama.2009.1535

6. Patroniti N, Zangrillo A, Pappalardo F, Peris A, Cianchi G, Braschi A, et al. The Italian ECMO network experience during the 2009 influenza $\mathrm{A}\left(\mathrm{H}_{1} \mathrm{~N}_{1}\right)$ pandemic: Preparation for severe respiratory emergency outbreaks. Intensive Care Med. 2011;37(9):1447-57. DOI: https:// doi.org/10.1007/s00134-011-2301-6

7. Takeda S, Kotani T, Nakagawa S, Ichiba $S$, Aokage T, Ochiai R, et al. Extracorporeal membrane oxygenation for 2009 influenza $\mathrm{A}\left(\mathrm{H}_{1} \mathrm{~N}_{1}\right)$ severe respiratory failure in Japan. ] Anesth. 2012;26(5):650-7. DOI: https://doi. org/10.1007/s00540-012-1402-x

8. Rojas-Suarez ], Paternina-Caicedo A, Cuevas L, Angulo S, Cifuentes R, Parra E, et al. Maternal mortality due to pandemic influenza $A$ $\mathrm{H}_{1} \mathrm{~N} 12009$ virus in Colombia. J Perinat Med. 2014;42(1):19-26. DOI: https://doi.org/10.1515/ jpm-2013-0140 